\title{
PRODUCTIVITY OF SUMMER ONION TO DIFFERENT SOURCES AND LEVELS OF POTASH
}

\author{
M.S. Naher*, S. Brahma, M.A. Islam, M.B. Sarkar, M.M. Hasan and A.H.F. Fahim \\ Spices Research Centre, Shibganj, Bogra, Bangladesh Agricultural Research Institute, Bangladesh \\ "Corresponding Author: mahmud.nahar@yahoo.com \\ Key words: Summer Onion; Potassium; Level; Source; Bulb Yield
}

\begin{abstract}
A field experiment was conducted at the research field of the Spices Research Centre, Shibganj, Bogra, Bangladesh in the summer season of 2013-2014 to find out the response of summer onion (var. BARI Peaj-3) to different levels and sources of potassium application. The experiment was laid out in a randomized complete block design with three replications. Potassium fertilizer combinations were comprised of four levels $\left(0,60,120\right.$ and $\left.180 \mathrm{~kg} \mathrm{ha}^{-1}\right)$ and two potassium sources viz. Potassium Chloride $(\mathrm{KCl})$ and Potassium Sulphate $\left(\mathrm{K}_{2} \mathrm{SO}_{4}\right)$. A significant improvement in different growth and yield parameters of onion was observed in response to different sources and levels of potassium. The results indicated that the maximum plant height, leaves plant $^{-1}$, length of leaf, length of bulb, diameter of bulb, average bulb weight, number of bulb per $\mathrm{m}^{2}$ and yield of bulbs were obtained from the onion crop which was treated with $120 \mathrm{~kg} \mathrm{~K} \mathrm{ha}^{-1}$ from the Sulphate of Potash (SOP) fertilizer. Among the treatments the highest bulb yield (14.33 $\mathrm{t} \mathrm{ha}^{-1}$ ) was obtained with $120 \mathrm{~kg} \mathrm{~K} \mathrm{ha}^{-1}$ and the lowest $\left(6.92 \mathrm{t} \mathrm{ha}^{-1}\right)$ from the control. The highest disease incidents $(65.67 \%)$ were recorded from the control followed by the plots which were treated with $60 \mathrm{~kg} \mathrm{~K} \mathrm{ha}^{-1}(62.28 \%)$. The lowest disease incidence (49.22\%) was recorded from $180 \mathrm{kgha}^{-1}$ SOP treated plot. Application of $120 \mathrm{~kg} \mathrm{~K} \mathrm{ha}{ }^{-1}$ from $\mathrm{K}_{2} \mathrm{SO}_{4}$ along with a blanket dose of $\mathrm{N}_{100} \mathrm{P}_{50} \mathrm{~S}_{20} \mathrm{~B}_{1.5} \mathrm{Zn}_{4} \mathrm{kgha}^{-1}$ and 5 ton cowdung ha-1 appeared to be the optimum dose for maximizing the bulb yield of summer onion.
\end{abstract}

\section{Introduction}

Onion (Allium cepa L.) is one of the important commercial vegetable and spice crops of Bangladesh. It produces 17.04 lakh mt of onion from 4.19 lakh acres area (BBS, 2015). The average yield of onion in Bangladesh is far below $11 \mathrm{t} \mathrm{ha}^{-1}$ (BBS, 2015) as compared to the world average of $19.32 \mathrm{t} \mathrm{ha}^{-1}$. Onion is mainly produced in the winter season.but cultivation in summer season is constrained due to adverse weather and proper cultural practices (Islam et al, 2008). By introducing drought tolerant onion varieties along with good cultural management, this may help increase onion production in Bangladesh. BARI has released three summer onion varieties for cultivating in the summer season. There is a significant response of onion to both inorganic and organic fertilizer (Nasreen et al., 2000 and Ullah, 2003). Potassium plays an important role in onion production and responsive to potash application like other tuber and root crops. Among the various nutrients required to produce high yield of onion, potassium is considered to be very important element due to its influence on translocation of photosynthates, storage quality, bulb size, bulb numbers and yield per plant (Sangakara et al., 1993). Potassium is one of the three major nutrients taken up by the plant in large quantities and an adequate level of potassium increases crop resistance to various diseases, stalk and stem breakage during stress conditions (Razzaque et al., 1990). Chloride in $\mathrm{KCl}$ may cause burning 
Naher et al.

of the leaves and deteriorate the onion bulbs; on the other hand sulphur in $\mathrm{K}_{2} \mathrm{SO}_{4}$ improves the quality of the onion bulbs. Among different sources of potassium, Sulphate of potash (SOP) contains sulfur that may lead to more growth and development as compared to Muriate of potash (MOP) for onion production (Nabi et al, 2010). Therefore, the experiment was undertaken to determine the response of summer onion (var. BARI Peaj-3) to different levels and sources of Potassium application.

\section{Materials and Methods}

The experiment was conducted at the experimental fields of Spices Research Centre in Bogra,Bangladesh. The experimental site represents Agro-Ecological Zone (AEZ)-26 as "Level Barind Tract" and situated at 24 51' North latitude and 8922 East longitude (FAO, 1988). The soil of the experimental field belongs to Grey Terrace Soil. It was developed from Madupur Clay and silty loam in texture. Organic matter content of the soil was low (1.02\%). The soil was acidic in nature ( $\mathrm{pH}$ 5.7). Total $\mathrm{N}$ and the exchangeable $\mathrm{K}$ status of the soil were also low. The available phosphorus, sulphur, boron and zinc contents were found to be either at par or below the critical level (Table 1). Summer onion var. BARIPiaz 3 was used as a test crop.

Table 1. Physical and chemical characteristics of the initial soil

\begin{tabular}{|c|c|c|c|c|c|c|c|c|c|c|c|}
\hline Texture & $\mathrm{pH}$ & $\mathrm{OM}$ & 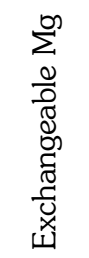 & 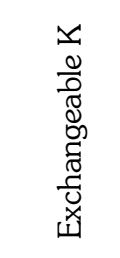 & 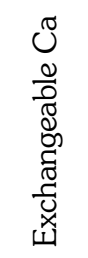 & $\begin{array}{l}z \\
\frac{\sigma 0}{0} \\
0 \\
\qquad\end{array}$ & $\begin{array}{l}0 \\
\frac{0}{0} \\
\frac{0}{0} \\
\frac{0}{0} \\
\frac{2}{4}\end{array}$ & 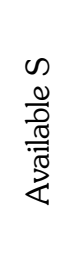 & 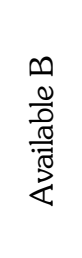 & 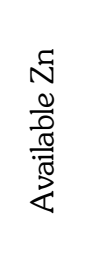 & 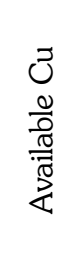 \\
\hline & & $\%$ & & $\mathrm{c} \mathrm{mol} \mathrm{kg}$ & & & \multicolumn{5}{|c|}{ (mg kg-1 soil) } \\
\hline Silt loam & 5.7 & 1.02 & 1.06 & 0.10 & 3.03 & 0.071 & 11.2 & 8.6 & 0.14 & 0.56 & 0.07 \\
\hline $\begin{array}{c}\text { Critical } \\
\text { level }\end{array}$ & - & - & 0.8 & 0.20 & 2.0 & - & 14 & 14 & 0.2 & 2.0 & 0.2 \\
\hline
\end{tabular}

There were Seven treatment combinations viz. $\mathrm{T}_{1}$ : $0 \mathrm{~kg} \mathrm{~K} \mathrm{ha-1}$ (Control), $\mathrm{T}_{2:} 60 \mathrm{~kg} \mathrm{~K} \mathrm{ha-1}$ from $\mathrm{KCl}, \mathrm{T}_{3}: 120 \mathrm{~kg} \mathrm{~K} \mathrm{ha}^{-1}$ from KCl, T $4: 180 \mathrm{~kg} \mathrm{~K} \mathrm{ha}^{-1}$ from KCl, T5: $60 \mathrm{~kg} \mathrm{~K} \mathrm{ha}^{-1}$ from K $\mathrm{SO}_{4}$, $\mathrm{T}_{6:} 120 \mathrm{~kg} \mathrm{~K} \mathrm{ha}^{-1}$ from $\mathrm{K}_{2} \mathrm{SO}_{4}$ and $\mathrm{T}_{7:} 180 \mathrm{~kg} \mathrm{~K} \mathrm{ha}^{-1}$ from $\mathrm{K}_{2} \mathrm{SO}_{4}$. The experiment was laid out in Randomized Complete Block design (RCBD) with three replications. Fertilizer with a blanket dose of $\mathrm{N}_{100} \mathrm{P}_{50} \mathrm{~S}_{20} \mathrm{~B}_{1.5} \mathrm{Zn}_{4} \mathrm{~kg} \mathrm{ha}^{-1}$ and cowdung (5tha ${ }^{-1}$ ) was used. The experimental plots were prepared uniformly and mixed with well-decomposed cow dung. Apart from potassium, all other fertilizers were applied to the soil during final land preparation. Urea fertilizer was applied with three equal splits at basal, 20 DAT and 40 DAT, respectively. The size of seedbed was $3 \mathrm{~m} 1 \mathrm{~m}$ with $20 \mathrm{~cm}$ height. The onion seeds were directly sown in the raised seedbed followed by irrigation. About 40 days old seedlings were uprooted from the seedbed and transplanted in the morning to the main field with the spacing of $10 \mathrm{~cm} 15 \mathrm{~cm}$ followed by irrigation. Intercultural operations like gap fillings, weeding and mulching were done whenever required. Second and third irrigation was given at 20 and 30 DAT, respectively. Insect and diseases were also controlled with appropriate control measures. Data 
of plant height $(\mathrm{cm})$, length of leaf $(\mathrm{cm})$ and number of leaves per plant were recorded from the selected five plants in each plot at 30, 50, 70 and 90 days after transplanting (DAT). The plant height $(\mathrm{cm})$ was taken from the neck of the onion bulb to the tip of the longest leaf. The leaf length $(\mathrm{cm})$ was measured from the pseudo stem to the tip of the leaf and the number of leaves from each plant. Onions were harvested when more than $40 \%$ of leaves tops were bent down (Khan and Khan, 1990 and Khokhar and Jilani, 2000). The bulbs were placed for five days under partial shade in the open for curing. Yield components data (length of bulb per plant $(\mathrm{cm})$, diameter of bulb per plant $(\mathrm{cm})$, single weight of bulb $(\mathrm{g})$, number of bulbs per plot and yield of bulb ( $\mathrm{t} \mathrm{ha}{ }^{-1}$ ) were collected and statistically analyzed using MSTAT-C computer package program (Russel, 1994). The significance of the differences among the pairs of treatment means was evaluated by the Duncan Multiple Range Test (DMRT) at 5\% level of probability (Gomez, et al, 1984).

\section{Results and Discussion}

\section{Plant height}

The plant height was significantly influenced by different sources and levels of potash (Table2). At 70 DAT, the highest plant height $(50.78 \mathrm{~cm})$ was recorded from $120 \mathrm{~kg} \mathrm{~K}^{-1}$ from $\mathrm{K}_{2} \mathrm{SO}_{4}$ source and the lowest plant height $(39.85 \mathrm{~cm})$ from the control.. Similar effect was also recorded at 30,50 and 90 DAT. The rate $120 \mathrm{~kg} \mathrm{~K}$ ha $^{-1}$ from $\mathrm{K}_{2} \mathrm{SO}_{4}$ showed the best performance which might be due to the availability of optimum source and level of potassium than other treatment. Hassanpouraghdam etal., (2008) also reported that different concentrations of $\mathrm{N}$ and $\mathrm{K}$ influenced height of the plants, the greatest height being observed in $\mathrm{N}$ and $\mathrm{K}$ with $200 \mathrm{mg} \mathrm{L-1each}$ and concluded that different concentrations of $\mathrm{N}$ and $\mathrm{K}$ have remarkable effects on the growth. Sulphate of potash produced significantly taller plants $(60.58$ $\mathrm{cm})$ as compared to Muriate of potash $(59.04 \mathrm{~cm})$. This may be due to the availability of more readily available forms of potassium and sulfur than other sources.

\section{Length of leaf}

Length of leaf of summer onion was significantly influenced by different sources and levels of potash (Table 2). At 70 DAT, the highest leaf length $(44.09 \mathrm{~cm})$ was recorded from $120 \mathrm{~kg} \mathrm{~K}$ $\mathrm{ha}^{-1}$ from $\mathrm{K}_{2} \mathrm{SO}_{4}$ source and the lowest plant height $(34.10 \mathrm{~cm})$ from control $\left(0 \mathrm{kgK} \mathrm{ha}{ }^{-1}\right)$. Similar effects were also observed at 30, 50 and 90 DAT. The rate $120 \mathrm{~kg} \mathrm{~K} \mathrm{ha}^{-1}$ from $\mathrm{K}_{2} \mathrm{SO}_{4}$ showed the best performance which might be due to the availability of the optimum source and level of potassium than other treatments. Pettigrew (2008) reported that potassium deficiency can lead to a reduction in the size of individual leaves.

\section{Number of leaves plant ${ }^{-1}$}

Table 2 shows significant differences among the different treatments. At 70 DAT, the maximum number of leaves per plant (7.58) was recorded from $120 \mathrm{~kg} \mathrm{~K} \mathrm{ha}^{-1}$ from $\mathrm{K}_{2} \mathrm{SO}_{4}$ source and the lowest (5.52) from control. Similar effect was also recorded at 30, 50 and 90 DAT. The rate $120 \mathrm{~kg} \mathrm{~K} \mathrm{ha}{ }^{-1}$ from $\mathrm{K}_{2} \mathrm{SO}_{4}$ showed the best performance compare to MOP application. Similarly Pettigrew (2008) reported that potassium deficiency can lead to a reduction in both the number of leaves and the size of individual leaves. 
Naher et al.

Table 2. Effect of different sources and levels of potash on yield components of summer onion

\begin{tabular}{|c|c|c|c|c|c|c|c|c|c|c|c|c|}
\hline \multirow[b]{2}{*}{ Treatment } & \multicolumn{3}{|c|}{30 DAT $^{*}$} & \multicolumn{3}{|c|}{$50 \mathrm{DAT}$} & \multicolumn{3}{|c|}{70 DAT } & \multicolumn{3}{|c|}{90 DAT } \\
\hline & $\begin{array}{c}\text { Plant } \\
\text { height } \\
(\mathrm{cm})\end{array}$ & $\begin{array}{l}\text { Length } \\
\text { of leaf } \\
(\mathrm{cm})\end{array}$ & $\begin{array}{c}\text { Number } \\
\text { of leaves } \\
\text { per } \\
\text { plant }\end{array}$ & $\begin{array}{c}\text { Plant } \\
\text { height } \\
(\mathrm{cm})\end{array}$ & $\begin{array}{l}\text { Length } \\
\text { of leaf } \\
(\mathrm{cm})\end{array}$ & $\begin{array}{l}\text { Number } \\
\text { of leaves } \\
\text { per plant }\end{array}$ & $\begin{array}{c}\text { Plant } \\
\text { height } \\
(\mathrm{cm})\end{array}$ & $\begin{array}{l}\text { Length } \\
\text { of leaf } \\
(\mathrm{cm})\end{array}$ & $\begin{array}{l}\text { Number } \\
\text { of leaves } \\
\text { per plant }\end{array}$ & $\begin{array}{l}\text { Plant } \\
\text { height } \\
(\mathrm{cm})\end{array}$ & $\begin{array}{l}\text { Length } \\
\text { of leaf } \\
(\mathrm{cm})\end{array}$ & $\begin{array}{c}\text { Number } \\
\text { of leaves } \\
\text { per } \\
\text { plant }\end{array}$ \\
\hline $\begin{array}{lll}\mathrm{T}_{1:} & 0 & \mathrm{~kg} \\
\mathrm{~K} \mathrm{ha}^{-1} & \end{array}$ & $21.32 \mathrm{f}$ & $16.11 \mathrm{f}$ & $3.02 \mathrm{~g}$ & $28.62 f$ & $22.52 \mathrm{~g}$ & $4.11 e$ & $39.85 \mathrm{~g}$ & $34.10 f$ & $5.52 \mathrm{~g}$ & $35.66 e$ & $30.65 \mathrm{~g}$ & $4.31 \mathrm{f}$ \\
\hline $\begin{array}{l}\mathrm{T}_{2:}: 60 \mathrm{~kg} \\
\mathrm{Kha}^{-1} \\
\text { from } \mathrm{KCl}\end{array}$ & $23.88 e$ & $18.38 e$ & $3.28 f$ & $30.75 e$ & $24.44 f$ & 4.66de & $42.56 f$ & $37.45 e$ & $6.05 f$ & $38.45 d$ & $33.29 f$ & $4.55 e$ \\
\hline $\begin{array}{l}\mathrm{T}_{3}: \quad 120 \\
\mathrm{~kg} \quad \mathrm{Kha}^{-1} \\
\text { from } \mathrm{KCl}\end{array}$ & $33.52 b$ & $27.88 \mathrm{c}$ & $4.38 \mathrm{~d}$ & $35.87 d$ & $29.71 d$ & $5.55 \mathrm{~cd}$ & $45.52 d$ & $41.22 \mathrm{~d}$ & $6.55 \mathrm{~d}$ & $41.44 \mathrm{c}$ & $36.07 d$ & $5.22 \mathrm{c}$ \\
\hline $\begin{array}{lr}\mathrm{T}_{4:} & 180 \\
\mathrm{~kg} & \mathrm{Kha}^{-1} \\
\text { from } \mathrm{KCl}\end{array}$ & $32.44 c$ & $26.96 c$ & $4.48 c$ & $36.96 c$ & $30.88 c$ & $5.65 c$ & $46.78 c$ & $42.35 c$ & $6.78 c$ & $42.51 \mathrm{c}$ & $37.11 \mathrm{c}$ & $5.29 b$ \\
\hline $\begin{array}{l}T_{5:} 60 \mathrm{~kg} \\
\mathrm{Kha}^{-1} \\
\text { from }\end{array}$ & $25.88 \mathrm{~d}$ & $21.67 d$ & $3.88 e$ & $32.25 e$ & $26.67 e$ & $5.18 \mathrm{~d}$ & $44.29 e$ & 39.38de & $6.41 e$ & $39.28 d$ & $35.35 e$ & $4.80 \mathrm{~d}$ \\
\hline $\begin{array}{l}\mathrm{K}_{2} \mathrm{SO}_{4} \\
\mathrm{~T}_{6}: \quad 120 \\
\mathrm{~kg} \quad \mathrm{Kha}^{-1} \\
\text { from } \\
\mathrm{K}_{2} \mathrm{SO}_{4}\end{array}$ & $36.35 a$ & $31.01 \mathrm{a}$ & $5.71 a$ & $39.85 a$ & $35.88 a$ & $6.68 a$ & $50.78 a$ & $44.09 a$ & 7.58a & $47.01 \mathrm{a}$ & $39.89 a$ & $5.88 a$ \\
\hline $\begin{array}{l}\mathrm{T}_{7:} \quad 180 \\
\mathrm{~kg} \mathrm{Kha}^{-1} \\
\text { from } \\
\mathrm{K}_{2} \mathrm{SO}_{4}\end{array}$ & $36.24 a$ & $29.87 b$ & $5.30 b$ & $37.12 b$ & $33.66 b$ & $6.39 b$ & $48.11 b$ & $41.88 b$ & $7.08 b$ & $45.15 b$ & $36.01 b$ & $5.37 b$ \\
\hline CV (\%) & 5.6 & 4.8 & 3.6 & 4.72 & 4.8 & 5.02 & 3.8 & 3.6 & 4.65 & 3.88 & 3.96 & 4.56 \\
\hline
\end{tabular}

Means having common letters are not significantly different at $5 \%$ level of significance as per DMRT

* DAT = Days After Planting 


\section{Plant disease incidence (\%)}

There were significant differences among the different potash sources and various levels of potash treatment combinations. The Fig. 1 shows that the maximum disease incidence (65.67\%) was recorded in the control followed by $60 \mathrm{~kg} \mathrm{~K} \mathrm{ha}^{-1}$ from $\mathrm{KCl}(62.28 \%)$., while the minimum (49.22.17\%) in $180 \mathrm{~kg} \mathrm{~K} \mathrm{ha}^{-1}$ from $\mathrm{K}_{2} \mathrm{SO}_{4}$ source followed by 52.88 and $51.55 \%$ in 60 and $120 \mathrm{~kg} \mathrm{~K} \mathrm{ha}^{-1}$ from $\mathrm{K}_{2} \mathrm{SO}_{4}$ source, respectively. Mandal et al. (2008) reported that application of $40 \mathrm{~kg} \mathrm{~K} \mathrm{ha}{ }^{-1}$ reduced percent disease index (PDI) by more than $10 \%$ compared with $0 \mathrm{kgKha}^{-1}$. Muriate of potash treated plot comparatively produced significantly higher disease incidence as compared to Sulpfate of Potash. The presence of the sulfur element in the Potassium Sulphate, may have increased the disease tolerance characters in the plants.

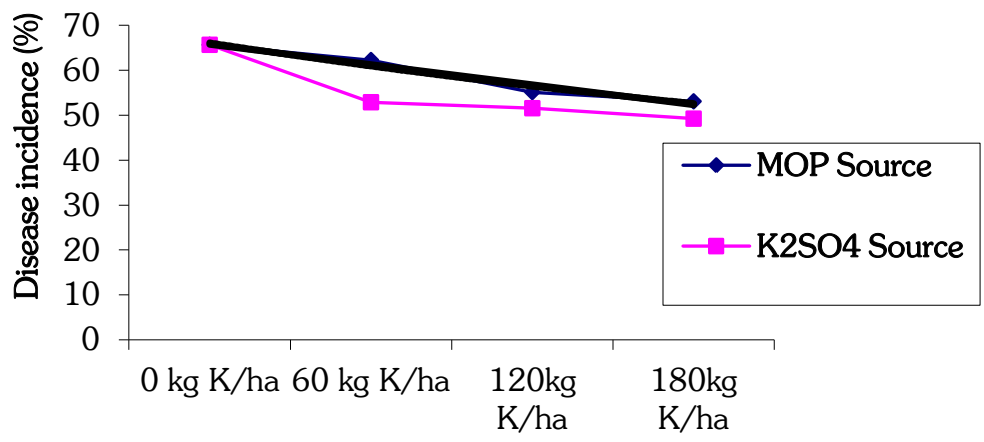

Levels of potash

Fig. 1 Effect of different sources and levels of potash on disease incidence (\%) in Summer onion

\section{Bulb Characters}

The number of harvested bulbs per square meter, bulb diameter and average bulb weight of summer onion were statistically significant (Table 3). The highest length of bulb $(4.21 \mathrm{~cm})$ was observed from $120 \mathrm{~kg} \mathrm{~K} \mathrm{ha}{ }^{-1}$ of $\mathrm{K}_{2} \mathrm{SO}_{4}$ and the lowest length of bulb $(2.36 \mathrm{~cm})$ by $0 \mathrm{~kg} \mathrm{~K} \mathrm{ha}{ }^{-1}$. The highest diameter of bulb $(4.25 \mathrm{~cm})$ was recorded from $120 \mathrm{~kg} \mathrm{~K} \mathrm{ha}{ }^{-1}$ of $\mathrm{K}_{2} \mathrm{SO}_{4}$ and the lowest $(2.78 \mathrm{~cm})$ from the control. The maximum bulb weight $(52.14 \mathrm{~g})$ was recorded from the treatment combination with $120 \mathrm{~kg} \mathrm{ha}^{-1}$ potassium from $\mathrm{K}_{2} \mathrm{SO}_{4}$ and the lowest bulb weight $(14.01 \mathrm{~g})$ from basal application of $0 \mathrm{~kg} \mathrm{Kha}^{-1}$. The highest number of bulbs $\mathrm{m}^{-2}$ (50.00) was recorded from $120 \mathrm{~kg} \mathrm{ha}{ }^{-1}$ potassium from $\mathrm{K}_{2} \mathrm{SO}_{4}$ and the lower number (41.00) from potassium control treated plot.

\section{Yield of bulbs}

There were significant differences among the different potash sources and various levels of potash. The maximum bulbs yield (14.33 $\left.\mathrm{t} \mathrm{ha}^{-1}\right)$ was recorded with potash at $120 \mathrm{~kg} \mathrm{ha}^{-1}$ of $\mathrm{K}_{2} \mathrm{SO}_{4}$ followed by $13.95 \mathrm{t} \mathrm{ha}^{-1}$ with $180 \mathrm{~kg} \mathrm{Kha}^{-1}$ from $\mathrm{K}_{2} \mathrm{SO}_{4}$ (Figure 2). The bulb yield increase with the increasing level of $\mathrm{K}$ upto $120 \mathrm{Kg} \mathrm{ha}^{-1}$. It indicates that application of $120 \mathrm{~kg}$ $\mathrm{K} \mathrm{ha}^{-1}$ from $\mathrm{K}_{2} \mathrm{SO}_{4}$ at vegetative as well as bulb formation stage was much better than the other levels of $\mathrm{K}$. The minimum bulb yield $\left(6.92\right.$ tha $\left.^{-1}\right)$ was recorded in control plot, followed by $10.44 \mathrm{t} \mathrm{ha}^{-1}$ with $60 \mathrm{~kg} \mathrm{~K} \mathrm{ha}^{-1}$ from KCl. According to Nabi et al., (2010) Sulphate of potash treated crop produced higher yield as compared to MOP. 
Naher et al.

Table 3. Effect of different sources and levels of potash on yield contributing characters of summer onion

\begin{tabular}{|c|c|c|c|c|c|}
\hline Treatment & $\begin{array}{l}\text { Length of } \\
\text { bulb }(\mathrm{cm})\end{array}$ & $\begin{array}{l}\text { Diameter } \\
\text { of bulb } \\
(\mathrm{cm})\end{array}$ & $\begin{array}{l}\text { Wt. of } \\
\text { single } \\
\text { bulb (g) }\end{array}$ & $\begin{array}{c}\text { No. of } \\
\text { bulb m }{ }^{-2}\end{array}$ & $\begin{array}{c}\text { Bulb } \\
\text { yield } \\
\text { (t ha-1) }\end{array}$ \\
\hline $\mathrm{T}_{1:} 0 \mathrm{~kg} \mathrm{~K} \mathrm{ha}^{-1}$ & $2.36 e$ & $2.78 e$ & $14.01 \mathrm{~g}$ & $41 \mathrm{~d}$ & $6.92 \mathrm{f}$ \\
\hline $\mathrm{T}_{2} .60 \mathrm{~kg} \mathrm{~K} \mathrm{ha}^{-1}$ from $\mathrm{KCl}$ & $3.51 \mathrm{~d}$ & $3.55 \mathrm{~d}$ & $26.06 \mathrm{f}$ & $44 c$ & $10.44 e$ \\
\hline $\mathrm{T}_{3}: 120 \mathrm{~kg} \mathrm{~K} \mathrm{ha}^{-1}$ from KCl & $4.07 \mathrm{ab}$ & $4.11 \mathrm{a}$ & $47.88 \mathrm{~b}$ & $47 \mathrm{~b}$ & $13.68 \mathrm{ab}$ \\
\hline $\mathrm{T}_{4:} 180 \mathrm{~kg} \mathrm{~K} \mathrm{ha}^{-1}$ from $\mathrm{KCl}$ & $4.01 b$ & $4.06 \mathrm{~b}$ & $44.56 \mathrm{~d}$ & $45 c$ & $12.98 \mathrm{c}$ \\
\hline $\mathrm{T}_{5}: 60 \mathrm{~kg} \mathrm{~K} \mathrm{ha}^{-1}$ from $\mathrm{K}_{2} \mathrm{SO}_{4}$ & $3.54 c$ & $3.60 c$ & $29.78 e$ & $46 b$ & $11.41 \mathrm{~d}$ \\
\hline $\mathrm{T}_{6:} 120 \mathrm{~kg} \mathrm{~K} \mathrm{ha}^{-1}$ from K${ }_{2} \mathrm{SO}_{4}$ & $4.21 \mathrm{a}$ & $4.25 \mathrm{a}$ & $52.14 a$ & $50 a$ & $14.33 a$ \\
\hline $\mathrm{T}_{7:} 180 \mathrm{~kg} \mathrm{~K} \mathrm{ha}^{-1}$ from $\mathrm{K}_{2} \mathrm{SO}_{4}$ & $3.98 b$ & $4.02 \mathrm{~b}$ & $45.22 \mathrm{c}$ & $49 \mathrm{ab}$ & $13.95 b$ \\
\hline CV (\%) & 3.75 & 4.32 & 3.66 & 5.32 & 4.88 \\
\hline
\end{tabular}

Means having common letters are not significantly different at $5 \%$ level of significance

\section{Conclusion}

On the basis of results, it was clearly showed that application of $120 \mathrm{~kg} \mathrm{~K} \mathrm{ha}^{-1}$ from $\mathrm{K}_{2} \mathrm{SO}_{4}$ along with a blanket dose of $\mathrm{N}_{100} \mathrm{P}_{50} \mathrm{~S}_{20} \mathrm{~B}_{1.5} \mathrm{Zn}_{4} \mathrm{~kg}$ ha' ${ }^{-1}$ and 5 ton cowdung ha ${ }^{-1}$ appeared as optimum dose for maximizing the bulb yield of summer onion of var. BARIPiaz-3 in AEZ-25 of Level Barind Tract, Bangladesh.

\section{References}

BBS (Bangladesh Bureau of Statistics), 2015. Statistics Division, Ministry of planning, Govt. of the People's Republic of Bangladesh. Dhaka. pp: 140.

FAO (Food and AgriculturalOrganization), 2013.(http://faostat.fao.org/site/339/default.aspx). (electronic resource). Accssed: 2016-11-16). Food and Agricultural Organization of the United Nations, Rome, Italy.

Gomez, K. A. and A. A. Gomez, 1984. Statistical Procedure for Agricultural Research (2 Edn.). John Willey and sons, Singapore. pp: 28-192.

Hassanpouraghdam, M. B., S. J. Tabatabaie, H. Nazemiyeh and A. Aflatunu, 2008. N and K nutrition levels affect growth and essential oil content of costmary ( Tanacetum balsamita L.). J. Food, Agr. \& Environ, 6(2): 150-154.

Islam, M. A., A. T. M. Shamsuddoha, M. S. I. Bhuiyan and M. Hasanuzzaman, 2008. Response of Summer Onion to Potash and its Application Methods. American-Eurasian Journal of Agronomy 1 (1): 10-15.

Nasreen, S. and A. K. M. Hossain, 2000. Influence of chemical fertilizers and organic manure on the growth and yield of onion. Bangladesh J. Agric. Res., 25(2): 221-231.

Nabi, G., A. Rab, S. J. Abbas, Farhatullah, F. Munsif and I. H. Shah, 2010. Influence of different levels of potash on the quantity, quality and storage life of onion bulbs. Pak. J. Bot., 42(3): 2151-2163. 
Pettigrew, W. T., 2008. Potassium influences on yield and quality production for maize, wheat, soybean and cotton (electronic resource). Physiologia plantarum, 133(4): 670-681.

Razzaque, A. H. M., M. I. Ali and A. K. M. Habibullah, 1990. Response of Boro rice to potassium application in two soils of Bangladesh. Bangladesh J. Soil Sci., 21(1): 26-29.

Sangakara, U.R. and E.R. Piyadasa, 1993. Influence of potassium on bulb characteristics of shallot. Intl. Symp. on Alliums for the tropics, Bangkok, 15-19 Feb. 1993. pp: 54.

Ullah, M.M., 2003. Nutrien management in summer onion. Ph.D. Thesis. Dept. of Soil Science. Bangabandhu Sheikh Mujibur Rahman Agric. Univ., pp: 150. 